\title{
Controlled trial of balneotherapy in treatment of low back pain
}

\author{
K Konrad, T Tatrai, A Hunka, E Vereckei, I Korondi
}

\begin{abstract}
Three treatments for non-specific lumbar pain-balneotherapy, underwater traction bath, and underwater massage-were assessed in a randomised prospective controlled trial in 158 outpatients. Each group was treated for four weeks and patients were reviewed at the end of this period and at 12 months after entry to the trial.

The prescription of analgesics and the pain score were significantly reduced in all three treated groups, but there was no difference between the three groups. No significant change occurred in spinal motion and the straight leg raising test. After one year only the analgesic consumption was significantly lower than in the control group.
\end{abstract}

About $80 \%$ of people will experience some back pain during their active life. ${ }^{1-3}$ In most cases the condition is self limiting with recovery within one month in $70 \%$ and within two or three months in $90 \%$, though for about $4 \%$ duration of pain exceeds six months. ${ }^{2}$ Recurrences are frequent, and three or more episodes have been reported in $30-70 \%$ of patients. ${ }^{124}$

In its various forms, low back pain is a devastating individual, social, and economic burden with costs estimated at $\$ 20$ billion per year annually in the United States, and about $10 \%$ of that amount per year in the United Kingdom. Low back pain is the most important cause of disability in industry in Sweden: between 1952 and 1982 the number of people taking early retirement owing to rheumatic diseases increased by $290 \%$, and this was almost entirely attributable to low back pain and sciatica. $^{5}$

Back pain usually affects subjects during their most productive years, accounting for $10-15 \%$ of all lost work days in Sweden. ${ }^{6}$ Among manual workers in England the annual absence from work because of back pain is about 70 weeks per 100 employed. ${ }^{7}$

Our study aimed at confirming the therapeutic effect of balneotherapy.

\section{Patients and methods}

The trial was carried out in three different factories in Budapest, where 2541 subjects were engaged in light industrial work. All subjects were informed of the purpose of the investigation, and 845 industrial workers consented to examination by rheumatologists. Standard, structured questionnaires were used. Three hundred and seventy of the 845 employees had low back pain when examined and the rest had no low back pain at all.

Criteria for admission to the trial were $(a)$ back pain localised to the lumbosacral region, with or without radiation to the thigh; $(b)$ duration of pain before entry to the trial of at least one month, but no longer than three months; (c) a pain free year before onset of the current episode. Criteria for exclusion of patients from the trial were pregnancy, back surgery, spondylolisthesis, infections, tumours, fractures, ankylosing spondylitis, senile osteoporosis, structural scoliosis.

One hundred and seventy patients were admitted to the trial and were randomly allocated to one of four groups in each factory: group A for balneotherapy, group B for underwater traction bath, group $\mathrm{C}$ for underwater massage, and group $\mathrm{D}$ as a control group. Twelve patients (group E) dropped out of the studythree in group $\mathrm{A}$ and nine in group $\mathrm{C}$. The five groups were comparable for age, sex, and medical care history. Table 1 gives details of the groups at the time of entry into the study.

Each patient was assessed on admission, after the four week treatment, and after one year. The following indices were recorded at each assessment: $(a)$ pain score according to a $0-100$ $\mathrm{mm}$ visual analogue scale; $(b)$ the number of analgesic tablets (non-steroidal anti-inflammatory drugs) taken during the 24 hours immediately preceding the assessment; $(c)$ the straight leg rising angle in each leg measured with a goniometer; $(d)$ flexion, extension, and lateral flexion of the lumbar spine measured with a goniometer. The investigator assessing the outcome was not aware of the treatment given.

For statistical analysis the following techniques were used: cross table analysis $\left(\chi^{2}\right)$, matched pairs $t$ test, and the SPSS program package for the IBM personal computer.

\section{METHODS OF TREATMENT}

Group A were treated by balneotherapy, with warm water, which provides minerals (table 2), heat, and buoyancy. This offers rheumatological rehabilitation by providing vasodilatation, relaxation, and an analgesic effect. The patients were just immersed in the thermal water and carried out no exercise. 
Table 1 Patient details given as mean (SD)

\begin{tabular}{|c|c|c|c|c|c|}
\hline \multirow[t]{2}{*}{ Characteristics } & \multicolumn{3}{|l|}{ Treatment ${ }^{*}$} & \multirow{2}{*}{$\begin{array}{l}\text { Control } \\
\begin{array}{l}(\text { iroup } D \\
(n=53)\end{array}\end{array}$} & \multirow{2}{*}{$\begin{array}{l}\begin{array}{l}\text { Treatment } \\
\text { dropout }\end{array} \\
\begin{array}{l}\text { Group } \\
(n=12)\end{array}\end{array}$} \\
\hline & $\underset{(n=35)}{\text { Group }} A$ & $\underset{(n=44)}{\text { Group }} B$ & $\underset{(n=26)}{\operatorname{Group}} C$ & & \\
\hline $\begin{array}{l}\text { Age (years) } \\
\text { Sex: } M / F \\
\text { Duration of back pain }\end{array}$ & $\begin{array}{l}42(8 \cdot 8) \\
15 / 20\end{array}$ & $\begin{array}{l}39(9 \cdot 1) \\
21 / 23\end{array}$ & $\begin{array}{l}44(7 \cdot 6) \\
11 / 15\end{array}$ & $\begin{array}{l}41(8 \cdot 6) \\
24 / 29\end{array}$ & $\begin{array}{l}37(9 \cdot 4) \\
4 / 8\end{array}$ \\
\hline $\begin{array}{l}\text { (months) } \\
\text { Number of analgesic } \\
\text { tablets taken } \neq:\end{array}$ & $2 \cdot 5(1 \cdot 1)$ & $2 \cdot 7(1 \cdot 4)$ & $2 \cdot 7(1 \cdot 8)$ & $2 \cdot 4(1 \cdot 7)$ & $2 \cdot 8(1.9)$ \\
\hline $\begin{array}{l}\text { On admission } \\
\text { After four weeks } \\
\text { After one year }\end{array}$ & $\begin{array}{ll}4 \cdot 8 & (3 \cdot 2) \\
2 \cdot 3 & (1 \cdot 3) \dagger \\
1.9 & (1 \cdot 8) \dagger\end{array}$ & $\begin{array}{ll}5 \cdot 1 & (2 \cdot 9) \\
2 \cdot 2 & (0 \cdot 9) \dagger \\
2 \cdot 1 & (1 \cdot 2) \dagger\end{array}$ & $\begin{array}{ll}4 \cdot 9 & (3 \cdot 4) \\
1 \cdot 8 & (0 \cdot 7) \dagger \\
2 \cdot 3 & (1 \cdot 7) \dagger\end{array}$ & $\begin{array}{l}5 \cdot 1(2 \cdot 8) \\
3 \cdot 9(2 \cdot 7) \\
3 \cdot 7(1 \cdot 9)\end{array}$ & $\begin{array}{l}5 \cdot 0(3 \cdot 1) \\
4 \cdot 1(2 \cdot 3) \\
3 \cdot 9(2 \cdot 1)\end{array}$ \\
\hline $\begin{array}{l}\text { Visual analogue pain } \\
\text { score }(0-100 \mathrm{~mm})\end{array}$ & & & & & \\
\hline $\begin{array}{l}\text { On admission } \\
\text { After four weeks } \\
\text { After one year }\end{array}$ & $\begin{array}{ll}63 \cdot 4 & (24 \cdot 1) \\
31 \cdot 7 & (16 \cdot 2) \dagger \\
49 \cdot 5 & (25 \cdot 7)\end{array}$ & $\begin{array}{ll}56 \cdot 7 & (28 \cdot 2) \\
24 \cdot 6 & (11 \cdot 9) \dagger \\
45 \cdot 8 & (26 \cdot 2)\end{array}$ & $\begin{array}{l}68 \cdot 4(31 \cdot 8) \\
33 \cdot 5(19 \cdot 1) \dagger \\
54 \cdot 7(33 \cdot 7)\end{array}$ & $\begin{array}{l}61 \cdot 5(32 \cdot 8) \\
53 \cdot 7(23 \cdot 8) \\
54 \cdot 9(24 \cdot 8)\end{array}$ & $\begin{array}{l}59 \cdot 8(29 \cdot 7) \\
51.8(27 \cdot 2) \\
53.1(23 \cdot 4)\end{array}$ \\
\hline
\end{tabular}

${ }^{*}$ Group $A=$ balneotherapy; group $B=$ underwater traction bath; group $C=$ underwater massage

$f \mathrm{p}<0 \cdot 01$.
$\ddagger$ Tablets taken during the 24 hours immediately before the assessment.

Table 2 Composition of the warm water. The amount of minerals dissolved in 1 litre of water is given

\begin{tabular}{|c|c|c|c|}
\hline & $m g$ & mmol & mmol $(\%)$ \\
\hline $\begin{array}{l}\mathbf{K}^{+} \\
\mathrm{Na}^{+} \\
\mathrm{Li}^{+} \\
\mathrm{Ca}^{2+} \\
\mathrm{Sr}^{2+} \\
\mathbf{M g}^{2+} \\
\mathbf{F e}^{2^{+}}\end{array}$ & $\begin{array}{r}4.94 \\
22 \cdot 85 \\
0.20 \\
117.20 \\
0.70 \\
42 \cdot 30 \\
0.2\end{array}$ & $\begin{array}{l}0.13 \\
0.99 \\
0.03 \\
5.86 \\
0.01 \\
3.50 \\
-\end{array}$ & $\begin{array}{r}1 \cdot 21 \\
9 \cdot 46 \\
0.27 \\
55 \cdot 70 \\
0.15 \\
33.13 \\
0.07\end{array}$ \\
\hline Total cations & $188 \cdot 39$ & $10 \cdot 52$ & $99 \cdot 99$ \\
\hline $\begin{array}{l}\mathrm{NO}_{3}^{-} \\
\mathrm{NO}_{2}^{-} \\
\mathrm{Cl}^{-} \\
\mathrm{SO}_{4}^{2-} \\
\mathrm{HCO}_{3}^{-} \\
\mathrm{BO}_{2}^{-}\end{array}$ & $\begin{array}{r}4 \cdot 00 \\
-\quad 27 \cdot 58 \\
109 \cdot 90 \\
445 \cdot 30 \\
0.43\end{array}$ & $\begin{array}{c}0.06 \\
0.78 \\
2.29 \\
7.30 \\
0.01\end{array}$ & $\begin{array}{r}0.62 \\
7.43 \\
21.92 \\
69.93 \\
0.09\end{array}$ \\
\hline Total anions & $587 \cdot 21$ & $10 \cdot 44$ & 99.99 \\
\hline $\begin{array}{l}\mathrm{H}_{2} \mathrm{SiO}_{3} \\
\mathrm{CO}_{2}\end{array}$ & $\begin{array}{r}16 \cdot 10 \\
109 \cdot 60\end{array}$ & - & - \\
\hline Total & $901 \cdot 30$ & 20.96 & \\
\hline
\end{tabular}

Group B were treated by underwater massage, which consisted of massage and movement while a stream of hot water $\left(37^{\circ} \mathrm{C}, 1 \mathrm{~atm}, 10 \mathrm{~cm}\right)$ played on the affected part.

Group $C$ were treated by underwater traction, during which the patient is fixed perpendicularly in a special deep pool, a bar is grasped under the arms and traction is applied. For the first treatment the patient's own weight was used, and next time, in addition to the traction due to gravity, a traction belt was applied to the pelvis with $3 \mathrm{~kg}$ weight on both sides. ${ }^{8}$

Patients received this treatment after work, and no other treatment was given during the ensuing months. All treatments were carried out in the same warm water $\left(37^{\circ} \mathrm{C}\right)$ in the same hospital for 15 minutes, three times a week, for four weeks. All the patients were taught to use their back correctly. Only non-steroidal antiinflammatory drugs were offered to control patients.

\section{Results}

One hundred and fifty eight patients completed the trial. The treatment was well tolerated by all patients. Fifty three patients in the control group received no treatment at all. As shown in table 1 , after one month, immediately after the course of balneotherapy, analgesic consumption was significantly less $(p<0.01)$ in the treated groups but not in the control group. At no time was there any statistical difference in analgesic consumption between the three groups. A similar pattern was seen for pain score, with all three treated groups recording a reduction of pain after one month $(p<0 \cdot 01)$. Reduced pain was evident in the control group as well, but the difference was not significant. Measurements of the ranges of spinal motion and straight leg raising at one month (data not shown) were compared with those made initially. No significant change occurred, though most patients thought that the treatment had been helpful.

After one year further information was obtained from 158 of the 170 patients. Most thought that their backs were better than when they had first been seen, but there was no difference between the different groups. There was a dramatic reduction in the number of daily dosage units consumed during treatment with balneotherapy, however, which was well maintained over the year $(p<0.01)$. There was no reduction in analgesic consumption in the control group.

\section{Discussion}

A large number of treatments are used for patients with low back pain, probably because little is known about the structural changes causing the symptoms. The effect of different treatments has been investigated rarely. Mathews, in a blind controlled study, attempted to assess the relative merits of manipulation, traction, and epidural and sclerosant injections. In all his groups women obtained greater pain relief than the control group. ${ }^{9}$ Traction therapy for low back pain in a double blind study has also been carried out. ${ }^{10}$ Clinical evaluation of the results for groups undergoing no traction, light traction, and normal traction showed no differences. $^{10}$ Another controlled trial of continuous lumbar traction showed similar improvements in both treated and control groups. ${ }^{11}$ Autotraction in a controlled pro- 
spective study gave significantly more pain relief than treatment with only a corset and rest. ${ }^{12}$

Historically, hydrotherapy-especially spa treatment-has been used for centuries in the treatment of back pain. Tradition rather than scientific evidence accounts for its continued use. A few trials have indicated that balneophysical measures are effective in the treatment of chronic low back pain, ${ }^{13-15}$ but none was controlled and their methodology is controversial. Balneotherapy has not been subject to controlled trials, ${ }^{16-18}$ except sulphur bath and mud pack treatment for rheumatoid arthritis. ${ }^{19}$ Although exercises have been proved to be effective, ${ }^{20}$ we could find volunteers only for balneotherapy, as this treatment has a long tradition and a good reputation in Hungary.

No difference in the effects of the three different types of balneotherapy could be shown at any time. One explanation might be that because we were dealing with outpatients, only two $3 \mathrm{~kg}$ weights were used for the group receiving underwater traction, whereas with inpatients we generally use two 6 or $9 \mathrm{~kg}$ weights.

We emphasise that this study was carried out only on people who were working full time, and had 'non-specific back pain'. Thus, as outpatients they received only one form of treatment, whereas patients attending rheumatological and orthopaedic clinics usually receive several forms of treatment.

The result suggests, on the one hand, that most patients with back pain obtain relief without any specific treatment, and that although balneotherapy may speed up this improvement, it makes no difference to the long term prognosis. On the other hand, balneotherapy seems to be a useful physiological means of reducing pain and analgesic consumption. Our management of low back pain is not so perfect that we can afford to ignore any form of treatment that can be shown to work.

1 Hult L. The Munkforks investigation. Acta Orthop Scand Suppl 1954; 16: 5-102.

2 Horal J. The clinical appearance of low back disorders in the city of Götenborg, Sweden. Comparisons of incapacitated probands with matched controls. Acta Orthop Scand 1969; suppl 118: 1-109.

3 Nachemson A L. The lumbar spine: an orthopedic challenge. Spine 1976; 1: 59-71.

4 Valkenburg H A, Haanen H C M. The epidemiology of low back pain. In: White A A, Gordon S L, eds. AAOS symposium of idiopathic low back pain. 1984: 9-22.

5 Nettelbladt E. Antalet reumatikerinvalider i Sverige under en 30 arsperiod Opmear (Sweden) 1985; 30: 54-6.

6 Helander E. Ryggbesvar och arbetsoförmaga. Socialmed $T$ 1973; 50: 398-404.

7 Anderson J A D. Back pain in industry. In: Jayson M, ed. The lumbar spine and back pain. London: Pitman Medical 1976: 57-82.

8 Bene E. Das Gewichtsbad. Z Phys Med Baln Klim 1988; 17: Mathews J A, Mills S B, Jenkins V M, et al. Back pain and sciatica: controlled trials on manipulation, traction, sclerosant and epidural injections. Br $\mathcal{f}$ Rheumatol 1987; 26: 424-9.

10 Reust $\mathrm{P}$, Chantraine A, Vischer T L. Traitement par traction mécaniques des lombosciatalgies avec ou sans déficit
neurologique. Schweiz Med Wochenschr 1988; 118: 271-4.

$11 \mathrm{Pal} \mathrm{B}$, Mangion P, Hossain M A, et al. A controlled trial of continuous lumbar traction in the treatment of back pain and sciatica. $\mathrm{Br} \mathcal{F}$ Rheumatol 1986; 25 : 181-3.

12 Larsson U, Chöler U, Lidström A, et al. Auto-traction for treatment of lumbago-sciatica. A multicentre controlled investigation. Acta Orthop Scand 1980; 51: 791-8.

13 Jackel W, Cziske R, Jacobi E. Einfluss balneophysikalischer Massnahmen wahrend einer stationaren Rehabilitation auf den Gesundhaitszustand von Patienten mit chronischen Kreuzschmerzen. Z Phys Med Baln Med Klim 1987; 16: 59-64.

14 Langridge J C, Phillips D. Group hydrotherapy exercises for chronic back pain sufferers. Physiotherapy 1988; 74: 269-73.

15 Bouvenot G, Bartolin R, Noblet M, et al. Essai de caracterisation d'un group de 394 lombalgiques chroniques vus a la isation d'un group de 394 lombalgiques chroniques vus a la
station thermal de Gréaux les Bains. Rhumatologie 1987; 87: station the

16 Simon L, Moltman F. Exercise therapy and hydrotherapy in the treatment of the rheumatic diseases. Clin Rheum Dis 1981; 7: 337-47.

17 Saloheimo E, Klaukka T, Sievers K. Controlled clinical trials in physical medicine. Helsinki: Social Insurance Institution. 1986: Finland series AL 30.

18 Deyo $\mathrm{R}$ A. Conservative therapy for low back pain. FAMA 1983; 250: 1057-62.

19 Sukenik S, Buskila D, Neumann L, Kleiner-Baumgarten A, Zimlichman S, Horowitz J. Sulphur bath and mud pack treatment for rheumatoid arthritis at the Dead Sea area. Ann Rheum Dis 1990; 49: 99-102.

20 Berquist-Ullmann M, Larsson U. Acute low back pain in industry. Acta Orthop Scand Suppl 1977: 170. 